\title{
RESPONS PERTUMBUHAN TANAMAN TOMAT (Solanum lycopersicum L) TERHADAP PEMBERIAN JAMUR Trichoderma sp
}

\author{
Nova Haryani $1^{1}$, Syaiful Eddy ${ }^{2}$, Dewi Novianti ${ }^{3}$ \\ ${ }^{1,2,3}$ Program Studi Biologi, Fakultas Matematika dan Ilmu Pengetahuan Alam \\ Universitas PGRI Palembang \\ *e-mail: novaharyani201995@gmail.com
}

\begin{abstract}
Research Response of Tomato Plant Growth (Solanum lycopersicum L.) against the provision of Trichoderma sp Mushrooms, from April to June 2019 at the MIPA Faculty Workshop, University of Palembang PGRI, South Sumatra. This study aims to determine. The growth Response of Tomato Plants to the administration of Trichoderma sp. This research method uses a completely randomized design with 6 treatments and 4 replications, namely P0 (without Trichoderma sp pellets), P1 (20 grams of Trichoderma sp pellets $/ \mathrm{kg}$ soil), P2 (40 grams of Trichoderma sp pellets/kg soil), P3 (60 grams of Trichoderma sp pellets $/ \mathrm{kg}$ soil), P4 (80 grams of Trichoderma sp pellets $/ \mathrm{kg}$ soil), P5 (100 grams of Trichoderma sp pellets/kg soil), analyzed by ANSIRA at the level of 5\%. The parameters observed in this study were plant height, stem diameter and number of leaves. Sidik Ragam Analysis result that the administration of Trichoderma sp significantly affected plant height, stem 80 grams of Trichoderma sp pellets/kg soil with an average plant height of $15,75 \mathrm{~cm}$, stem diameter of $1,2 \mathrm{~mm}$, and number of leaves of 18,75 strands, while the lowest yield was in a flat treatment without Trichoderma sp plant height $3 \mathrm{~cm}$, stem diameter $0,1 \mathrm{~mm}$, and number of leaves 4 strands.
\end{abstract}

Keywords: Trichoderma sp, growth, tomatoes (Solanum lycopersicum)

\begin{abstract}
ABSTRAK
Penelitian Respons Pertumbuhan Tanaman Tomat (Solanum lycopersicum L.)Terhadap Pemberian Jamur Trichoderma sp, pada bulan April sampai dengan bulan Juni 2019 di Workshop Fakultas MIPA Universitas PGRI Palembang, Sumatera Selatan. Penelitian ini bertujuan untuk mengetahui respons pertumbuhan tanaman tomat terhadap pemberian jamur Trichoderma sp. Metode penelitian ini menggunakan Rancangan Acak Lengkap dengan 6 perlakuan dan 4 ulangan yaitu P0 (tanpa pelet Trichoderma sp), P1 (20 gram pelet Trichoderma sp/kg tanah), P2 (40 gram pelet Trichoderma sp/kg tanah), P3 (60 gram pelet Trichoderma sp/kg tanah), P4 (80 gram pelet Trichoderma sp/kg tanah), P5 (100 gram pelet Trichoderma $\mathrm{sp} / \mathrm{kg}$ tanah), dianalisis dengan ANSIRA pada taraf 5\%. Parameter yang diamati dalam penelitian ini adalah tinggi tanaman, diameter batang dan jumlah daun.Hasil Analisis Sidik Ragam bahwa pemberian Trichoderma sp berpengaruh nyata terhadap tinggi tanaman, diameter batang, dan jumlah daun. Perlakuan terbaik terdapat pada perlakuan 80 gram pelet Trichoderma $\mathrm{sp} / \mathrm{kg}$ tanah dengan rata-rata tinggi tanaman $15,75 \mathrm{~cm}$, diameter batang 1,2 mm, dan jumlah daun 18,75 helai, sedangkan hasil terendah pada perlakuan tanpa pelet Trichoderma sp dengan rata-rata tinggi tanaman $3 \mathrm{~cm}$, diameter batang $0,1 \mathrm{~mm}$, dan jumlah daun 4 helai.
\end{abstract}

Kata Kunci: Trichoderma sp, pertumbuhan, tomat (Solanum lycopersicum L.) 


\section{PENDAHULUAN}

Tomat merupakan komoditas sayuran yang memiliki nilai ekonomis yang tinggi.Tomat termasuk tanaman holtikultura dari familia Solanaceae. Buah tomat mengandung protein, karbohidrat, lemak, kalsium, fosfor, zat besi, vitamin $A$, vitamin $B$, dan vitamin C. Buah tomat merupakan komoditas yang bermanfaat untuk mengatasi resiko gangguan jantung, menurunkan kadar kolestrol, serta mengurangi resiko radang usus buntu (Yusuf, 2013).

Produktivitas tomat di Indonesia masih tergolong rendah. Menurut data BPS (2014) menyatakan bahwa produksi tomat di Indonesia pada tahun 2013 mencapai 992,780 ton dan telah mengalami penurunan pada tahun 2014 yaitu 915,987 ton. Belum optimalnya produktivitas diantaranya disebabkan oleh tingginya serangan hama dan penyakit yang dapat menurunkan produktivitas.

Pengendalian menggunakan fungisida sintetik relatif lebih mahal dan berpeluang mengganggu lingkungan serta berdampak negatif dalam mengendalikan penyakit-penyakit tanaman seperti terbunuhnya mikrooragnisme bukan sasaran dan membahayakan bagi kesehatan (Wilia $d k k ., 2011$ ).

Salah satu alternatif upaya peningkatan kuantitas dan kualitas produk pertanian khususnya tanaman tomat dapat dilakukan dengan pemanfaatan agen hayati yang ramah lingkungan dan berbasis sumber daya hayati sebagai pengganti pestisida sintetik. Salah satu jamur yang dapat digunakan sebagai biopestisida yang bersifat antagonis bagi patogen tanaman yaitu jamur Trichoderma sp. Trichoderma sp merupakan jamur tanah yang bersifat antagonis terhadap patogen tular tanah, bersifat mikroparasitik, mempunyai kemampuan menginduksi ketahanan tanaman terhadap berbagai penyakit dan dapat meningkatkan pertumbuhan tanaman (Juliana $d k k ., 2017)$.

Berdasarkan uraian di atas maka telah dilakukan penelitian dengan tujuan untuk mengetahui respons pertumbuhan tanaman tomat (Solanum lycopersicum L.) terhadap pemberian jamur Trichoderma sp.

\section{BAHAN DAN METODE}

Penelitian ini merupakan penelitian eksperimen menggunakan metode Rancangan Acak Lengkap (RAL) yang terdiri dari 6 perlakuan pemberian Trichoderma sp dan 4 ulangan yaitu :

$\mathrm{P}_{0}=$ Kontrol/ Tanpa pellet

$\mathrm{P}_{1}=20$ gram pellet $/ \mathrm{kg}$ tanah

$\mathrm{P}_{2}=40$ gram pelet $/ \mathrm{kg}$ tanah

$\mathrm{P}_{3}=60$ gram pelet $/ \mathrm{kg}$ tanah

$\mathrm{P}_{4}=80$ gram pelet $/ \mathrm{kg}$ tanah

$\mathrm{P}_{5}=100$ gram pelet $/ \mathrm{kg}$ tanah

Ket: 1gram pelet mengandung $16,47 \mathrm{x}$ $10^{6}$ konidia Trichoderma sp.

Data yang diperoleh dengan menggunakan analisis sidik ragam. Jika perlakuan berpengaruh nyata, maka dilanjutkan dengan uji lanjut BNT dengan membandingkan F-hitung dengan F-tabel pada taraf $\alpha 5 \%$

\section{HASIL DAN PEMBAHASAN}

Respons Pertumbuhan Tinggi Tanaman Tomat Terhadap Pemberian Jamur Trichoderma sp

Hasil ansira menunjukkan bahwa pemberian Trichoderma sp pada berbagai konsentrasi perlakuan berpengaruh nyata terhadap pertumbuhan tinggi tanaman tomat sehingga dilakukan uji lanjut (Tabel 1). Respons pemberian Trichoderma sp terhadap pertumbuhan tinggi tanaman tomat didapatkan rata-rata tinggi tanaman tertinggi pada perlakuan 
P4 (80 g pelet Trichoderma sp / $\mathrm{kg}$ tanah) yang menghasilkan rata-rata tinggi tanaman tomat $15,75 \mathrm{~cm}$, sedangkan hasil terendah pada perlakuan P0 (tanpa pelet Trichoderma sp) dengan rata-rata tinggi tanaman $3 \mathrm{~cm}$.

Respons Pertumbuhan Diameter Batang Tanaman Tomat Terhadap Pemberian Jamur Trichoderma sp

Hasil ansira menunjukkan bahwa pemberian Trichoderma sp pada berbagai konsentrasi perlakuan berpengaruh nyata terhadap diameter batang tanaman tomat (Tabel 2). Pada Tabel 2 menunjukkan bahwa hasil yang tertinggi didapat pada perlakuan P4 (80 g pelet Trichoderma sp/ $\mathrm{kg}$ tanah rata-rata diameter batang 1,2 $\mathrm{mm}$, sedangkan hasil terendah didapat pada perlakuan P0 (tanpa pelet Trichoderma $\mathrm{sp}$ ) dengan diameter batang $0,1 \mathrm{~mm}$.
Respon Pertumbuhan Junlah Daun Tanaman Tomat Terhadap Pemberian Jamur Trichoderma sp

Hasil ansira menunjukkan bahwa pemberian jamur Trichoderma sp pada berbagai konsentrasi perlakuan berpengaruh nyata terhadap pertumbuhan jumlah daun tanaman tomat (Tabel 3). respons pertumbuhan rata-rata jumlah daun tanaman tomat (Solanum lycopersicum L.) terhadap pemberian jamur Trichoderma sp dengan hasil yang tertinggi didapat pada perlakuan P4 (80 g pelet Trichoderma $\mathrm{sp} / \mathrm{kg}$ tanah) yang menghasilkan rata-rata jumlah daun 18,75 helai, sedangkan hasil terendah terdapat pada perlakuan P0 (tanpa pelet Trichoderma sp) dengan rata-rata jumlah daun 4 helai.

Tabel 1. Respons Tanaman Tomat (Solanum lycopersicum L.) terhadap Pemberian Jamur Trichoderma sp.

\begin{tabular}{ccl}
\hline Perlakuan & Rata-rata Tinggi Tanaman Tomat $(\mathbf{c m})$ \\
\hline P0 & $\mathbf{3}$ & $\mathbf{a}$ \\
P1 & 9,25 & $\mathrm{~b}$ \\
P2 & 10,5 & $\mathrm{~b}$ \\
P3 & 13,25 & $\mathrm{bc}$ \\
P4 & $\mathbf{1 5 , 7 5}$ & $\mathbf{c}$ \\
P5 & 12,25 & $\mathrm{~b}$ \\
\hline BNT $^{(\mathbf{0 , 0 5 \% )}: \mathbf{1 , 9 7}}$ & &
\end{tabular}

Keterangan : Rata-rata dalam tabel yang diikuti oleh huruf yang sama artinya tidak berbeda nyata pada uji BNT 5\%.

Tabel 2. Respons Diameter Batang Tanaman Tomat (Solanum lycopersicum L.) terhadap Pemberian Jamur Trichoderma sp.

Perlakuan Rata-rata Diameter Batang Tanaman Tomat (mm)

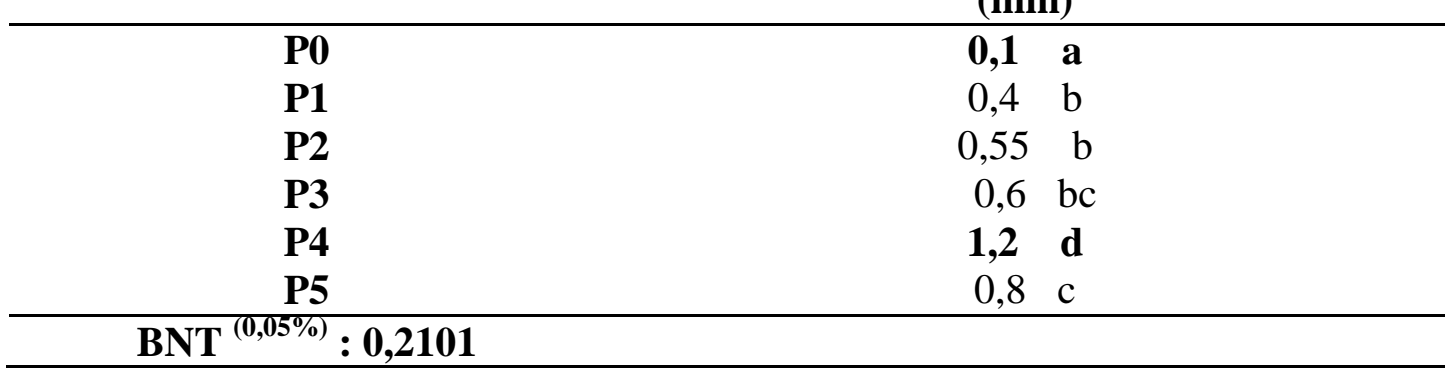

Keterangan : Rata-rata dalam tabel yang diikuti oleh huruf yang sama artinya tidak berbeda nyata pada uji BNT 5\%. 
Tabel 3. Hasil Uji BNT Rata-rata Jumlah Daun Tanaman Tomat (Solanum lycopersicum L.) Terhadap Pemberian Jamur Trichoderma sp.

\begin{tabular}{cc}
\hline Perlakuan & $\begin{array}{c}\text { Rata-rata Jumlah Daun Tanaman Tomat } \\
\text { (helai) }\end{array}$ \\
\hline P0 & $\mathbf{4}$ a \\
P1 & $10,25 \mathrm{~b}$ \\
P2 & 11,25 bc \\
P3 & $14,5 \mathrm{c}$ \\
P4 & $\mathbf{1 8 , 7 5} \mathbf{d}$ \\
P5 & $16,75 \mathrm{~d}$ \\
\hline BNT $^{(\mathbf{0 , 0 5 \% )}}: \mathbf{2 , 1 6}$ & \\
\hline
\end{tabular}

Keterangan : Rata-rata dalam tabel yang diikuti oleh huruf yang sama artinya tidak berbeda nyata pada uji BNT 5\%.

Dari Tabel 1, 2, dan 3 terlihat rata-rata pertumbuhan tinggi batang, diameter batang dan jumlah daun tanaman tomat tertinggi pada perlakuan P4 (80 g pelet Trichoderma $\mathrm{sp} / \mathrm{kg}$ tanah) menghasilkan rata-rata tinggi tanaman yaitu $15,75 \mathrm{~cm}$, diameter batang $1,2 \mathrm{~mm}$, dan jumlah daun sebanyak 18,75 helai, sedangkan paling terendah terdapat pada perlakuan P0 (tanpa pemberian pelet Trichoderma sp) menghasilkan rata-rata tinggi tanaman yaitu $3 \mathrm{~cm}$, diameter batang $0,1 \mathrm{~mm}$ dan jumlah daun sebanyak 4 helai. Pada perlakuan P0 setelah dipindahkan dari penyemaian tidak mengalami peningkatan pertumbuhan hal ini disebabkan karena tanah yang digunakan pada penelitian ini merupakan tanah yang sedikit memiliki kandungan unur hara. Berdasarkan data statistik tinggi tanaman tomat, diameter batang dan jumlah daun cenderung meningkat seiring dengan meningkatnya pemberian konsentrasi Trichoderma sp, tetapi pada perlakuan P5 (100 g pelet Trichoderma $\mathrm{sp} / \mathrm{kg}$ tanah) mengalami penurunan. Terjadinya penurunan tinggi tanaman, diameter batang, dan jumlah daun pada perlakuan tersebut dikarenakan jumlah komposisi Trichoderma sp yang terlalu banyak sehingga menghasilkan hormon auksin yang banyak juga. Hormon auksin diperlukan untuk tanaman dalam jumlah kadar yang optimum dapat berfungsi membantu pemanjangan akar sedangkan jika jumlah kadar auksinnya lebih tinggi malah akan dapat menghambat pemanjangan akar sehingga pertumbuhantanaman tomat tidak tumbuh secara normal (Apriliani $d k k ., 2015$ ).

Pertumbuhan tanaman tomat (Solanum lycopersicum L.) terhadap pemberian Trichoderma sp mengalami penurunan diduga akibat faktor lingkungan seperti suhu misalnya suhu dalam workshop yang terlalu tinggi pada siang hari yaitu kisaran $30^{\circ} \mathrm{C}-35^{\circ} \mathrm{C}$ yang menyebabkan tanaman tomat tidak tumbuh dengan normal pada umumnya atau menjadi faktor penghambat pertumbuhan tanaman tomat (Solanum lycopersicum L.) dan menyebabkan tanah cepat mengalami kekeringan. Kekeringan merupakan istilah untuk menyatakan bahwa tanaman mengalami kekurangan air akibat keterbatasan air dari lingkungan media tanamnya. Kekurangan air mempengaruhi semua aspek pertumbuhan tanaman, yang meliputi proses fisiologi, anatomi dan morfologi. Pada saat kekurangan air, sebagian stomata daun menutup sehingga terjadi hambatan masuknya $\mathrm{CO}_{2}$ dan menurunkan aktivitas fotosintesis, kekurangan air juga menghambat sintesis protein dan dinding sel. Tanaman yang mengalami kekurangan air secara umum mempunyai ukuran yang lebih kecil 
dibandingkan dengan tanaman yang tumbuh normal (Kurniasari $d k k, .2010$ ). Selain itu dapat pula disebabkan oleh adanya gangguan serangan hama yang terdapat pada saat penelitian. Hama yang ditemukan pada penelitian ini dapat mengganggu pertumbuhan tanaman tomat (Solanum lycopersicum L.). Hama yang ditemukan yaitu ulat kaki seribu (Narceus sp) yang dapat menggangu dan merusak tanaman. Spesies ini biasa berada didasar tanah dengan membentuk lubang-lubang pada tanah sehingga menyebabkan kerusakan pada akar dan dapat mengganggu kesuburan tanah. Selain disebabkan oleh suhu dan gangguan hama dapat juga disebabkan karena pemberian Trichoderma sp yang dilakukan hanya sekali membuat Trichoderma sp memerlukan waktu yang cukup lama untuk berkembang biak dan mendegranasi.

Menurut penelitian (Rizal $d k k ., 2019$ ) bahwa pemberian $25 \mathrm{~g}$ pelet Trichoderma $\mathrm{sp} / 2 \mathrm{~kg}$ tanah sudah mampu meningkatkan pertumbuhan tinggi tanaman dan jumlah daun pada tanaman tomat (Solanum lycopersicum L.). Pemberian Trichoderma sp berpengaruh sangat nyata pada pertumbuhan tinggi dan jumlah daun pada tanaman tomat, namun berpengaruh tidak nyata terhadap diameter tanaman tomat. Hasil penelitian tersebut menyatakan bahwa pertumbuhan tanaman tomat tertinggi yaitu terdapat pada perlakuan P5 (dosis 125 gram peletTrichoderma $\mathrm{sp} / 2 \mathrm{~kg}$ tanah) dengan tinggi tanaman $28,28 \mathrm{~cm}$, diameter $0,4 \mathrm{~cm}$, dan jumlah daun 14 helai sedangkan hasil terendah yaitu terdapat pada perlakuan P0. Hasil penelitian (Sepwanti $d k k ., 2016)$ bahwa pemberian $20 \mathrm{~g}$ pelet Trichoderma $\mathrm{sp} / \mathrm{kg}$ tanah mampu meningkatkan pertumbuhan tinggi tanaman tomat (Solanum lycopersicum L.). Penggunaan Trichoderma sp dapat memacu pertumbuhan tanaman pada tomat (Solanum lycopersicum L.) yang meliputi tinggi batang, diameter batang dan jumlah daun.Hubungan timbal balik antara Trichoderma sp dengan tanaman adalah bersifat mutualisme.Tanaman diuntungkan dalam hal pertumbuhan, sedangkan Trichoderma sp diuntungkan karena mendapatkan nutrisi yang dihasilkan oleh tanaman.Trichoderma $\mathrm{sp}$ berperan dalam meningkatkan kesuburan tanah dengan melakukan sintesis terhadap bahan organik sehingga membuat unsur hara tersedia bagi tanaman (Herlina dan Dewi, 2010).

\section{KESIMPULAN}

Pemberian jamur Trichoderma $\mathrm{sp}$ dapat meningkatkan pertumbuhan tinggi tanaman, diameter batang dan jumlah daun tanaman tomat.Perlakuan P4 (80 g pelet Trichoderma $\mathrm{sp} / \mathrm{kg}$ tanah) memberikan hasil tertinggi terhadap ratarata tinggi tanaman yaitu $15,75 \mathrm{~cm}$, diameter batang $1,2 \mathrm{~mm}$, dan jumlah daun 18,75 helai, sedangkan hasil terendah pada perlakuan tanpa pelet Trichoderma sp dengan rata-rata tingi tanaman $3 \mathrm{~cm}$, diameter batang $0,1 \mathrm{~mm}$, dan jumlah daun 4 helai.

\section{SARAN}

Perlu dilakukan penelitian lebih lanjut untuk mengetahui jumlah optimal Trichoderma sp yang dapat meningkatkan pertumbuhan tanaman tomat (Solanum lycopersicum L.).

\section{DAFTAR PUSTAKA}

Apriliani, A. Noli, Z.A. dan Suwirmen. 2015. Pemberian Beberapa Jenis dan Konsentrasi Auksin untuk Menginduksi Perakaran Pada Stek Pucuk Bayur Dalam Upaya Perbanyakan Tanaman Revegetasi.Jurnal Biologi Universitas Andalas 4(3): 178-187.

Badan Pusat Statistik dan Direktorat Jendral Holkultura. 2014. Komoditi Indonesia. Jakarta 
Herlina, L. dan Dewi, P. 2010.Penggunaan Kompos Aktif Trichoderma harzianum dalam Meningkatkan Pertumbuhan Tanaman Cabai. Jurnal Saians dan Teknologi 8(2): 25-36.

Juliana, Umrah, dan Asrul. 2017. Pertumbuhan Miselium Trichoderma sp pada Limbah Cair Tempe dan Limbah Air Kelapa.Jurnal Biocelebes11(2): 5459.

Kurniasari, A,M, Adisyahputra, R. dan Rosman.2010. Pengaruh kekeringan pada Tanah Beragam $\mathrm{NaCl}$ terhadap Pertumbuhan Tanaman Nilam. Jurusan Biologi FMIPA UI. Jakarta. Jurnal Ilmiah Saians 10(1): 86-90.

Rizal, S., D, Novianti., dan M, Septiani. Pengaruh Jamur Trichoderma sp Terhadap Pertumbuhan Tanaman Tomat (Solanum lycopersicum L). Jurnal Indobiosains 1(1): 14-21.

Sepwanti, C. Rahmawati, M. dan Kesumawati, E. 2016. Pengaruh Varietas dan Dosis Kompos yang Diperkaya Trichoderma harzianum terhadap Pertumbuhan dan Hasil Tanaman Tomat (Solanum lycopersicum L.).Jurnal Kawista1(1): 68-74.

Wilia, W.A. Yulia dan Trias, N. 2011. Eksplorasi Cendawan Endofit dari Beberapa Varietas Kedelai Sebgai Agens Pemacu Pertumbuhan Tanaman.Jurnal Unja 13(1): 93105.

Yusuf, 2013.Penyakit Tanaman Kelapa Sawit. Sekolah Tinggi Ilmu Pertanian Agrobisnsis Perkebunan (STIPAP) Medan. 